\title{
Effect of the Electrodeposition Potential of Platinum on the Catalytic Activity of a Pt/GC Catalyst Toward Formic Acid Electro-Oxidation
}

\author{
Islam M. Al-Akraa ${ }^{\text {l, }}$, Bilquis Ali Al-Qodami², Ahmad M. Mohammad ${ }^{2, *}$ \\ ${ }^{1}$ Department of Chemical Engineering, Faculty of Engineering, The British University in Egypt, Cairo \\ 11837, Egypt \\ ${ }^{2}$ Chemistry Department, Faculty of Science, Cairo University, Cairo 12613, Egypt \\ *E-mails: islam.ahmed@ bue.edu.eg (Islam M. Al-Akraa), ammohammad@cu.edu.eg (Ahmad M. \\ Mohammad)
}

doi: $10.20964 / 2020.05 .121$

Received: 10 October 2019 / Accepted: 9 December 2019 / Published: 10 April 2020

\begin{abstract}
The electrocatalytic activity of platinum (Pt)-modified glassy carbon (GC) (referred as Pt/GC) electrodes toward the formic acid electro-oxidation (FAO) was investigated. The Pt deposition on the GC substrate was carried out by a potentiostatic technique at different potentials (from $0.2 \mathrm{~V}$ to $-0.2 \mathrm{~V}$ vs. $\mathrm{Hg} / \mathrm{Hg}_{2} \mathrm{Cl}_{2} / \mathrm{KCl}$ (sat.) reference electrode) and the corresponding influence on the catalytic activity toward FAO was monitored. The electrocatalytic inspection revealed a potential role for the Pt deposition potential in boosting the catalytic efficiency of the catalyst toward FAO and further in mitigating the CO poisoning that eventually deactivate the catalyst. Interestingly, the highest activity toward FAO was obtained at the Pt/GC electrode for which $\mathrm{Pt}$ was electrodeposited at $0.05 \mathrm{~V}$. This was reflected from its high $\mathrm{I}_{p}{ }^{\mathrm{d}} / \mathrm{I}_{\mathrm{p}}$ ind $(20)$ and $\mathrm{I}_{\mathrm{p}}{ }^{\mathrm{d}} / \mathrm{I}_{\mathrm{b}}(0.83)$ ratios that were employed to assess the electrocatalytic performance of the catalyst.
\end{abstract}

Keywords: Formic acid electro-oxidation; Pt nanoparticles; Electrodeposition potential; Fuel cells.

\section{FULL TEXT}

(C) 2020 The Authors. Published by ESG (www.electrochemsci.org). This article is an open access article distributed under the terms and conditions of the Creative Commons Attribution license (http://creativecommons.org/licenses/by/4.0/). 